\title{
REFLUXUL GASTROESOFAGIAN LA NOU-NĂSCUT ŞI SUGAR (II)
}

\author{
Valeriu V. Lupu, Ancuța Ignat, Gabriela Păduraru, Marin Burlea \\ Disciplina Pediatrie, Universitatea de Medicină şi Farmacie „, Gr. T. Popa“, Iaşi
}

\begin{abstract}
REZUMAT
Refluxul gastroesofagian la nou-născut şi sugar se particularizează prin patogenie, încadrare diagnostică şi abordare terapeutică, imaturitatea funcțională a aparatului digestiv, imaturitatea anatomică a sfincterului esofagian inferior Hiss şi aciditatea gastrică mai mică. În cazul sugarilor se ține cont şi de complianța redusă la procedurile laborioase cum sunt $\mathrm{pH}$-metria, impedanț-pH-metria şi endoscopia degestivă. Granița dintre regurgitații, reflux gastroesofagian fiziologic şi boală de reflux este uneori dificil de trasat. Modificarea stilului de viață la sugari (alimentația şi modificările poziționale), prin obținerea aderenței mamei la recomandările medicale reprezintă un prim pas în tratamentul RGE, fiind urmat în cazurile non-responsive de terapia farmacologică şi intervenția chirurgicală.
\end{abstract}

Cuvinte cheie: reflux gastroesofagian, nou-născut, sugar

\section{TRATAMENTUL BRGE}

Opțiunile de tratament în refluxul gastroesofagian (RGE) fiziologic şi în boala de reflux gastroesofagian (BRGE) includ: modificări ale stilului de viață, terapia farmacologică şi chirurgia.

Modificarea stilului de viață la sugarii cu RGE fiziologic include alimentația şi modificările poziționale. Educarea părinților, ghidurile şi suportul moral sunt întotdeauna necesare şi, de obicei, suficiente pentru sugarii cu simptome de RGE fiziologic. În caz de RGE funcțional la sugarul mic, regurgitaţiile şi vărsăturile se rezolvă spontan până la vârsta de 1 an. Trebuie explicată părinților natura fiziologică, benignă a afecțiunii şi lămurită distincţia dintre refluxul fiziologic şi cel patologic. Părinții trebuie ascultați şi liniştiţi. Avem obligația să le înțelegem anxietatea, vorbindu-le despre istoria naturală a bolii. Informarea părinților trebuie să fie cât mai completă şi la obiect deoarece majoritatea manevrelor vor fi efectuate de către părinți.

\section{Măsuri dietetice}

Aproximativ 50\% din sugarii sănătoşi în vârstă de 3-4 luni prezintă cel puțin o regurgitație pe zi (26).
Atât sugarii alimentaţi la sân, cât şi sugarii alimentaţi cu formulă de lapte au o frecvență similară a refluxului fiziologic, dar durata episoadelor de reflux determinată prin monitorizarea $\mathrm{pH}$-ului poate fi mai scurtă la sugarii alimentați natural $(27,28)$.

Un studiu efectuat pe sugari a arătat că alimentarea cu un volum mare de lapte a determinat regurgitare, probabil prin creşterea frecvenței relaxării tranzitorii a SEI şi un volum redus de lapte a scăzut frecvența refluxului (29). Reducerea severă a cantității alimentare o perioadă îndelungată poate lipsi nou-născutul de energia calorică necesară şi poate afecta creşterea în greutatea. Sugarii cu greutate inadecvată din cauza pierderilor prin regurgitații pot beneficia de o creştere a energiei calorice prin formule speciale atunci când volumul sau frecvența alimentației sunt scăzute ca parte a terapiei (21).

Preparatele care îngroaşă mesele sau formulele îngroşate (Gelopectose 3-5\%, Gumilk 2\%) şi laptele antireflux determină diminuarea numărului regurgitațiilor; la fel şi alimentele consistente pentru sugari de tipul formulelor cu cereale par să reducă RGE. Acestea cresc vâscozitatea şi realizează un floculat fin, uşor evacuabil din stomac, rămânând în suspensie în lichidul gastric (30). 
Îngroşarea prânzurilor cu cereale de orez este asociată cu o scădere a numărului de episoade de vărsături, dar nu se înregistrează o îmbunătățire a indicelui de reflux (31). Există studii care susțin că formulele îngroşate pot reduce frecvența regurgitațiilor şi volumul total al unei vărsături. De asemenea, poate reduce timpul în care copilul plânge şi creşte timpul de somn al acestuia (32). Alte studii arată că îngroşarea prânzurilor poate să agraveze episoadele de tuse şi/sau alte simptome respiratorii în perioada postprandială (33). Cerealele de orez folosite cresc densitatea calorică a formulei şi pot provoca constipație. Îngroşarea laptelui este asociată cu un risc mai mare pentru enterocolită necrotică în rândul prematurilor.

De asemenea, se folosesc formule de lapte care sunt evacuate mai rapid din stomac. $\mathrm{Cu}$ cât formulele de lapte sunt mai bogate în cazeină, cu atât evacuarea este mai lentă. Cazeina floculează în mediul acid gastric (30).

Mediul ambiental tabagic se va suprima deoarece acesta scade presiunea SEI. De asemenea, trebuie evitate toate sursele de compresiune pe abdomen: înfăşatul sau îmbrăcămintea prea strânsă, bandaj antiherniar neadecvat sau manipulările intempestive care pot provoca regurgitații sau vărsături (30).

Prin urmare, la sugari alimentați cu formulă de lapte care prezintă regurgitații frecvente se recomandă următoarea abordare: se stabileşte istoricul alimentației, se reduce volumul prânzurilor numai dacă sunt în exces pentru greutatea copilului, se oferă prânzuri mai mici şi mai frecvente (menținând în acelaşi timp aceeaşi cantitate de lapte zilnică), cu excepția cazului în care prânzurile sunt deja mici şi frecvente, apoi se adaugă formule îngroşate (de exemplu, care contin amidon de orez, amidon de porumb sau făină de roşcove) (18).

La sugarii alimentaţi la sân care continuă să prezinte regurgitații în ciuda evaluării şi consilierii, se ia în considerare terapia cu alginat pentru o perioadă de 1-2 săptămâni. Dacă terapia cu alginat este benefică, se continuă cu ea, dar se opreşte această terapie la anumite intervale de timp, pentru a verifica dacă sugarul şi-a revenit (18).

La sugarii alimentați cu formule de lapte, dacă această abordare nu are succes, se opresc formulele de lapte îngroşate şi se administrează terapie cu alginat pentru o perioadă de 1-2 săptămâni. La fel ca şi la sugarii alimentați la sân, dacă terapia cu alginat este benefică, se continuă cu ea, dar se opreşte această terapie la anumite intervale de timp pentru a verifica dacă sugarul şi-a revenit (18).

Nu se administrează medicamente care suprimă aciditatea, precum inhibitorii de pompă protonică
(IPP), antagonişti ai receptorilor $\mathrm{H} 2$ pentru a trata sugarii cu regurgitații care apar ca simptom izolat (18).

\section{Recomandări posturale}

Iniţial s-a observat că poziționarea copilului în decubit ventral cu capul mai ridicat duce la rărirea şi scurtarea episoadelor de reflux, dar fără efecte semnificative asupra duratei refluxului (34). U1terior, posibilitatea apariției morții subite în această poziție a redus entuziasmul. În multe țări, s-a lansat chiar o campanie împotriva poziționării ventrale a sugarului datorită riscului de moarte subită. Această poziționare poate fi o modalitate utilă în cazul sugarulului în stare de veghe. Astfel, plasarea sugarului în stare de veghe, în poziție ventrală, cu capul într-o parte, la o înclinație de $30-45^{\circ}$ este eficientă în controlul regurgitaţiilor şi/sau vărsăturilor şi implicit a refluxului (35).

$\mathrm{Cu}$ ajutorul $\mathrm{pH}$-metriei s-a dovedit că poziția ventrală scade expunerea la refluatul acid a esofagului comparativ cu poziția dorsală (36).

Se evită poziția culcat pe spate sau semişezândă şi, de asemenea, se evită plasarea copilului în scaunul auto sau în orice poziţie şezândă după mese, putând exacerba RGE, prin creşterea presiunii intraabdominale.

Prin urmare, terapia posturală este o modalitate terapeutică utilă la copiii mici, cu poziționarea în plan înclinat la $35-40^{\circ}$ în decubit dorsal sub supraveghere.

\section{Tratamentul farmacologic}

Terapia farmacologică în BRGE are ca scop: ameliorarea simptomelor de reflux, prevenirea complicațiilor majore şi a intervenției chirurgicale, prevenirea recurențelor bolii. Tratamentul medicamentos este indicat în RGE patologic sau când tratamentul conservator (terapia posturală şi dietetică) nu a dat rezultatele scontate.

$\mathrm{Nu}$ este recomandată terapia cu IPP sau antagonişti ai receptorilor $\mathrm{H} 2$ pentru a trata sugarii $\mathrm{cu}$ regurgitatii care apar ca simptom izolat.

Se ia în considerare tratamentul pentru 4 săptămâni cu IPP sau antagonişti ai receptorilor H2 care nu sunt în măsură se relateze simptomele lor (sugari), care au regurgitaţii numeroase şi care prezintă dificultăți de alimentație (de exemplu, la ce cei cu refuz alimentar sau sufocare), comportament neobişnuit sau dificultăți de creştere.

Dacă simptomele nu se remit sau reapar după oprirea tratamentului cu IPP sau antagonişti ai receptorilor $\mathrm{H} 2$, se ia în considerare posibilitatea efectuării de endoscopie digestivă superioară (18). 
Când se alege IPP sau antagonişti ai receptorilor H2, se are în vedere disponibilitatea pentru vârsta respectivă, preferința părinților şi costul de achiziție.

IPP reprezintă cel mai eficient tratament care produce supresia acidului clorhidric, leagă covalent şi dezactivează pompele de protoni din celulele parietale (pompele $\mathrm{H}+/ \mathrm{K}+$ - ATP-ază). Datorită efectului lor antisecretor, reprezintă medicația de elecție în tratamentul RGE, determinând dispariţia simptomatologiei de reflux în peste $90 \%$ din cazuri (37). Acest tratament empiric se menține pe durata de 4-8 săptămâni şi se constituie într-un veritabil test diagnostic simplu şi cost-eficient, inclusiv pentru cei cu simptome extradigestive (38). Eficiența maximă este obținută când sunt administrați cu 1/2 oră înainte de micul dejun, astfel încât vârful de concentraţie plasmatică să coincidă cu momentul mesei, dacă se recurge la administrarea în 2 prize zilnice, cea de-a doua doză este administrată cu 1/2 oră înainte de masa de seară. IPP sunt reprezentaţi de benzimidazoli: Omeprazol, Pantoprazol, Lansoprazol, Esomeprazol, Rabeprazol. Autori francezi raportau o toxicitate ridicată pentru IPP: cefalee, vertij, somnolență, reacții cutanate, confuzie mentală, atingeri hematologice, hepatită (posibil cu formă fulminantă), tulburări digestive şi electrolitice, interacțiuni medicamentoase (39). Indicaţia de bază a tratamentului cu IPP rămâne leziunea de esofagită severă (eroziunea şi ulcerația esofagiană) sau esofagul Barrett. Administrarea IPP la cei cu reflux non-acid nu influențează volumul şi frecvența episoadelor de reflux față de cei cu reflux acid. Apariţia în cursul tratamentului cu IPP a unor „Scăpări acide“ nocturne (adică episod de reflux nocturn) este combătută cu dublarea dozei de IPP sau administrarea asociată de blocant pentru receptorii $\mathrm{H} 2$, intermitent, pentru a se preveni instalarea tahifilaxiei care se dezvoltă rapid în condițiile unei administrări continue.

Antagoniştii receptorilor $\mathrm{H} 2$ scad secreția acidă prin inhibarea receptorilor histaminici $\mathrm{H} 2$ de la nivelul celulelor parietale gastrice. Într-un studiu efectuat pe sugari, ranitidina $(2 \mathrm{mg} / \mathrm{kg} /$ doză $)$ a redus timpul în care $\mathrm{pH}$ a fost $<4$ cu $44 \%$ atunci când s-a administrat de două ori pe zi şi cu $90 \%$ atunci când s-a administrat de 3 ori pe zi (40). Dintre membrii seriei (Cimetidina, Ranitidina, Famotidina, Nizatidina), cei mai studiați şi utilizaţi în pediatrie sunt Ranitidina şi Nizatidina (41). Blocantele de receptori H2 sunt încă folosite ca terapie de primă linie pentru esofagitele uşoare şi medii, cu durata tratamentului de 6-8 săptămâni pentru esofagitele uşoare şi cu o durată a tratamentului de 3-4 luni pentru formele moderate de esofagită. Terapia cu antagoniştii receptorilor $\mathrm{H} 2$ este eficientă, dar utilizarea pe termen lung este limitată. Ei pot provoca tahifilaxie în termen de şase săptămâni şi pot creşte riscul de boli de ficat şi ginecomastie.

$\mathrm{Nu}$ se administrează metoclopramid, domperidon sau eritromicină pentru tratamentul RGE sau BRGE, având în vedere potențialul lor de a crea evenimente adverse (18).

Prokineticele pot reduce simptomele BRGE prin îmbunătățirea contractilității corpului esofagian, creşterea presiunii SEI şi creşterea ratei de golire gastrică. $\mathrm{Cu}$ toate acestea, beneficiile acestor agenţi nu pot depăşi efectele negative, care includ: somnolenţă, agitație şi reacții extrapiramidale. $\mathrm{Nu}$ există suficiente dovezi care să sprijine utilizarea de rutină a prokineticelor în BRGE la copii.

\section{Tratamentul chirurgical}

Pentru tratamentul chirurgical (fundoplicatură) se are în vedere efectuarea de endoscopie digestivă superioară cu prelevarea de biopsii. De asemenea, se poate efectua $\mathrm{pH}$-metrie sau impedant, $\mathrm{pH}$-metrie înaintea intervenției chirurgicale.

După ce diagnosticul de BRGE se confirmă, terapia chirurgicală se are în vedere la pacienții la care:

- managementul medical nu a avut succes (regurgitații severe necontrolate de tratament sau efecte adverse importante în urma tratamentului);

- se optează pentru intervenție chirugicală în ciuda tratamentului eficient (se ia în considerare calitatea vieții, administrarea de medicamente pe tot parcursul vieții, costul medicamentelor);

- apar complicații ale BRGE (esofag Barrett, stenoză peptică) $(42,43)$;

- prezintă manifestări extradigestive (disfonie, tuse cronică, pneumonie de aspirație) (44-46).

În plus, fundoplicatura la sugarii cu BRGE sever se efectuează când măsurile dietetice s-au dovedit ineficiente în cazul alimentării pe sondă-nazogastrică continuă pe termen lung cu formule îngroşate (18).

Fundoplicatura Nissen este metoda preferată, foarte eficace în controlul vărsăturilor. Se realizează pe cale chirurgicală clasică, iar în ultimul timp, tot mai multe centre recurg la intervenția pe cale laparoscopică, superioară tehnicilor clasice, datorită vizibilităţii mai bune şi caracterului mai puțin invaziv şi agresiv.

În general, chirurgia antireflux a fost mai atent evaluată la adulți decât la copii. Dintre copiii care au avut intervenție chirurgicală, cei cu tulburări 
neurologice au prezentat de 2 ori mai frecvent complicații, morbiditatea a fost de 3 ori mai mare, iar reintevenția chirurgicală a fost necesară de 4 ori mai frecvent decât la cei fără tulburări neurologice $(47,48)$.

Fundoplicatura în copilăria timpurie are o rată de eşec mai mare decât fundoplicatura efectuată mai târziu, în copilărie (49).

\section{EVOLUȚIA BRGE LA NOU-NĂSCUT ŞI SUGAR}

Consecințele refluxului pot deveni evidente încă din perioada neonatală şi de sugar mic. Se conturează la această vârstă forma emetizantă, forma hemoragică şi formele respiratorii sau cele cu expresie neurologică.

Hematemeza survine înainte de vârsta de 10 zile de viață (prin esofagită asociată adesea cu gastroduodenită) şi este principala cauză de hemoragie la această vârstă, fiind agravată de hipovitaminoza K; profilaxia cu vitamina $\mathrm{K}$ administrată sistematic în primele ore de viață devine astfel utilă, iar în unele țări se realizează până la 3 luni (de exemplu în Italia).

De asemenea, un RGE patologic poate determina accese de tip paroxistic, care au adesea un curs dramatic, cu crize de cianoză şi hipotonie, detresă respiratorie, dispnee laringiană sau crize de apnee, necesitând reanimare (marchează uneori moartea subită); manifestările sunt greu de corelat cu refluxul, dar răspunsul pozitiv la terapia antireflux şi testele de pH-metrie confirmă cauza.

În plus, la aceeaşi vârstă, nu sunt de neglijat şi alte consecințe ale reflux de tipul celor respiratorii: bronşiolite sau pneumopatii repetate, episoade nocturne de tuse şi wheezing, care în evoluție se transformă în boală respiratorie cronică, şi consecințe nutriţionale: stagnare în greutate, anemie hipocromă.

\section{PROGNOSTICUL BRGE}

Prognosticul pentru sugarii cu istoric de RGE fiziologic sau funcțional este foarte bun, cu vindecare chiar spontană şi completă.
Probleme ridică BRGE, unde modalitățile de tratament, răspunsul la terapie şi factorul timp joacă un rol decisiv.

$\mathrm{Ca}$ factori de prognostic nefavorabil pot fi consideraţi:

- diagnosticul tardiv, în faza de esofagită severă, stenoză esofagiană sau esofagul Barrett;

- copii encefalopaţi sau cu alte tare neurologice asociate sau tulburări de comportament; având în vedere faptul că sugarii cu retard psihomotor sunt afectați în peste o treime din cazuri de RGE. Aceştia dezvoltă leziuni extinse de esofagită care determină pe termen scurt anemie, iar pe termen lung, leziuni de stenoză esofagiană;

- alte boli asociate precum: sclerodermia, mucoviscidoza;

- tratament incorect, cu discordanță între tipul leziunii şi tipul de tratament utilizat;

- lipsa de complianță a pacienților sau părinților;

- rezistența la tratament (exemplu nonresponsivii la tratamentul cu IPP).

În concluzie, BRGE este o afecțiune cu prognostic bun, rezultatele terapeutice furnizate de toate datele din literatură sunt favorabile. Individualizarea fiecărui caz este obligatorie şi necesară.

\section{CONCLUZII}

Este importantă stabilirea cu exactitate a caracterului fiziologic sau patologic al refluxului gastroesofagian pentru cunoaşte abordarii terapeutice ulterioare.

Complianța redusă la procedurile laborioase (pH-metrie, impedanț-pH-metrie şi endoscopie digestivă superioară) fac ca examenul clinic şi relatările părinților să fie suficiente pentru diagnosticarea refluxului.

În cazul nou-născuților şi sugarilor este importantă aplicarea măsurilor dietetice şi a celor posturale care se impun în momentul în care apar regurgitațiile şi vărsăturile. 